\title{
STUDY ON SUGAR CANE BAGASSE ASH IN CONCRETE BY PARTIAL REPLACEMENT OF CEMENT
}

\author{
Prof. Maheshwari G Bisanal ${ }^{1}$, Prof. S. M. Chandrakanth ${ }^{2}$, Prof. Shankargouda Patil ${ }^{1}$, Mr. Samarth Khot ${ }^{1}$, \\ ${ }^{1}$ Department of Civil Engineering, KLECET, Chikodi - 591201, Karnataka, INDIA \\ ${ }^{2}$ Department of Civil Engineering, VSM's SRKIT, Nipani - 591237, Karnataka, INDIA
}

\begin{abstract}
Admixtures are commonly used in concrete to improve the properties of both fresh and hardened concrete. Mineral admixtures include Fly Ash (FA), Silica Fume (SF), Ground Granulated Blast Furnace Slag (GGBFS), Metakaolin (MK), and Rice Husk Ash (RHA) etc, which possess certain characteristics through which they influence the properties of concrete differently. In this study Sugar Cane Bagasse Ash (SCBA) has been used as a Mineral Admixture to improve the properties of concrete. Approximately 1500 Million tonnes of sugarcane is annually produced over all the world which leave about 40-45 \% bagasse after juice crushing for Sugar Industry giving an average annual production of 675 Million tonnes of bagasse as a waste material.
\end{abstract}

The utilization of industrial and agricultural waste produced by Industrial processes has been the focus of waste reduction, research for economic, environmental, and technical reasons. Sugarcane bagasse ash is one of the main byproduct can be used as mineral admixture due to its high content in silica ( $\mathrm{SiO2}$ ). In this study concrete Cubes, Cylinders and Prisms are casted with different percentages of Sugar cane bagasse ash replaced with cement by weight and Compressive strength, Split tensile strength and Flexural strength have been tested for 7 days, and 28 days.

Keywords - Sugar Cane Bagasse Ash, Admixture, Environment, Strength.

\section{INTRODUCTION}

In view of global warming, efforts should be made to reduce the emission of $\mathrm{CO} 2$ to the environment. Cement industry has a major contribution to the global warming, so in this study an attempt has been made to reduce the percentage of cement in making concrete by adding supplementary material called as Sugar Cane Bagasse Ash (SCBA). SCBA is also having a great disposal problem again it leads to the great environmental pollution. The use of SCBA in concrete can reduce the consumption of cement in making concrete and also reduce the disposal problem. For the experimental work, we have collected the SCBA from Dudhaganga sugar factory, which is near to Chikodi Tq. Belagavi Dist. Karnataka.

\section{INGREDIENTS USED IN MIX DESIGN}

Cement:

In this study 43 grade Ordinary Portland Cement conforming to BIS 12269 was used, the test results on cement sample are shown in below Table.

Table 1. Specific gravity of cement

\begin{tabular}{|c|c|}
\hline Properties & Results \\
\hline Specific gravity & 3.15 \\
\hline Finess of Cement & $3 \%$ \\
\hline Specific surface area & 3564.025 sq. cm/gm \\
\hline
\end{tabular}

Coarse Aggregates:

Aggregates are the important constituents in concrete. They give body to the concrete. In the present study Crushed stones of $20 \mathrm{~mm}$ down size were used as coarse aggregate. Properties of coarse aggregates are shown in below Table.

Table 2. Physical properties of Coarse Aggregates

\begin{tabular}{|c|c|}
\hline Properties & Results \\
\hline Aggregate impact value & $11.70 \%$ \\
\hline Aggregate crushing value & $14.88 \%$ \\
\hline Specific gravity & 2.5 \\
\hline Water absorption & $0.61 \%$ \\
\hline
\end{tabular}

Fine Aggregates:

Those fractions from $4.75 \mathrm{~mm}$ to 150 microns are termed as fine aggregates. The river sand and crushed sand is to be used in combination as fine aggregate conforming to the requirements of IS: 383 . In this study local river sand was used as fine aggregate in the concrete mixtures. Properties of fine aggregates are shown in below Table. 
Table 3. Physical properties of Fine Aggregates

\begin{tabular}{|c|c|}
\hline Properties & Results \\
\hline Specific gravity & 2.42 \\
\hline Finess modulus & $4.70 \%$ \\
\hline
\end{tabular}

Water:

Water is an important ingredient of concrete as it actually participates in the chemical reaction with cement.

Bagasse Ash:

Bagasse is a by-product during the manufacture of sugar and it has high calorific value. It is utilized as a fuel in boilers in the sugar mills to generate steam and electricity. The obtained Sugarcane Bagasse Ash causes a great disposal problem. Using waste SCBA as a pozzolanic material to replace cement can reduce the consumption of cement and reduce landfill area requirements. This is turn helps solve environmental issue caused by cement production, decreasing both energy based and $\mathrm{CO} 2$ emissions. Below Figure shows the production of Bagasse Ash in the Industry.
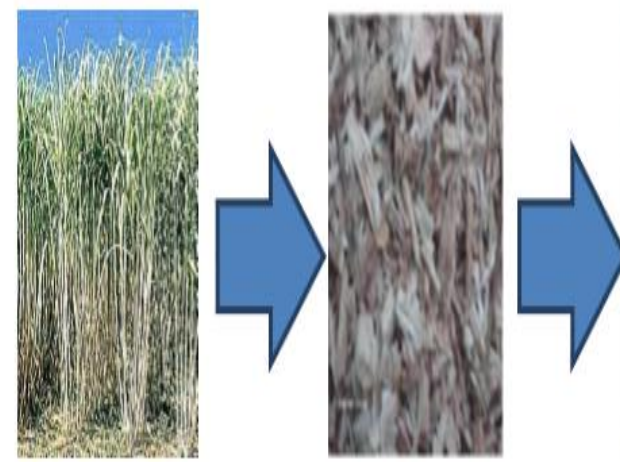

SUGARCANE

\section{BAGASSE}

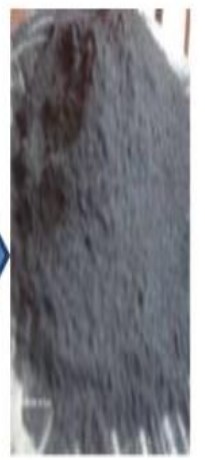

BAGASSE ASH
Fig. 1. Flow Diagram of Bagasse Ash Production

For the present study the Sugar Cane Bagasse Ash is collected from Dudha Ganga Sugar Industry, Nandi, Chikodi Tq. Belagavi Dist. Karnataka.

\section{EXPERIMENTAL WORK}

Mix Design:

Mix design can be defined as the process of selecting suitable ingredients of concrete and determining their relative proportions with the object of producing concrete of certain minimum strength and durability as economically as possible.
A mix M30 grade was designed as per Indian Standard (IS 10262-1982) method and the same was used to prepare the test samples.

Mix calculation:

$$
\begin{array}{ll}
\text { Cement } & =438 \mathrm{Kg} / \mathrm{m} 3 \\
\text { Water } & =197 \mathrm{litres} / \mathrm{m} 3 \\
\text { Coarse aggregate } & =1111.481 \mathrm{Kg} / \mathrm{m} 3 \\
\text { Fine aggregate } & =710.619 \mathrm{Kg} / \mathrm{m} 3
\end{array}
$$

Proportion:

$$
\text { M30 grade } \quad=1: 1.51: 2.40
$$

Concrete cubes, Cylinders and Prism have been prepared by varying percentage of Sugar Cane Bagasse Ash (SCBA) as a cement replacement material by $0 \%, 10 \%, 20 \%, 30 \%$ respectively and compressive strength, Split tensile strength and Flexural strength test had been conducted on samples for 7 and 28 days.

Compressive strength test is the most common test conducted on hardened concrete as it is an easy test to perform and also most of the desirable characteristic properties of concrete are qualitatively related to its compressive strength. The compression test is carried out on specimen cubical in shape.

Following Table shows average 7 days \& 28 days compressive strength of cubes prepared with varying percentage of Bagasse Ash.

Table 4. Average Compressive Strength of Concrete Cubes with varying percentage of Bagasse Ash (BA).

\begin{tabular}{|c|c|c|}
\hline \multirow{2}{*}{ Type of Concrete } & \multicolumn{2}{|c|}{ Compressive Strength in MPa } \\
\cline { 2 - 3 } & 7 days & 28 days \\
\hline Normal concrete & 17.18 & 31.62 \\
\hline $5 \%$ BA concrete & 18.15 & 33.92 \\
\hline $10 \%$ BA concrete & 20.14 & 39.69 \\
\hline $20 \%$ BA concrete & 24.84 & 42.19 \\
\hline $30 \%$ BA concrete & 24.03 & 34.50 \\
\hline
\end{tabular}

Similarly Table 5 and 6 shows average 7 days \& 28 days split tensile strength and flexural strength of concrete prepared with varying percentage of Bagasse Ash.

Table 5. Average Split Tensile strength of concrete cylinders with varying percentage of Bagasse Ash (BA).

\begin{tabular}{|c|c|c|}
\hline \multirow{2}{*}{ Type of Concrete } & \multicolumn{2}{|c|}{ Split Tensile Strengths in MPa } \\
\cline { 2 - 3 } & 7 days & 28 days \\
\hline Normal concrete & 1.35 & 2.44 \\
\hline
\end{tabular}




\begin{tabular}{|c|c|c|}
\hline 5\% BA concrete & 1.4 & 2.88 \\
\hline 10\% BA concrete & 1.45 & 3.53 \\
\hline $20 \%$ BA concrete & 1.67 & 3.81 \\
\hline $30 \%$ BA concrete & 1.17 & 2.8 \\
\hline
\end{tabular}

Table 6. Average Flexural Strength of Concrete Beam with varying percentage of Bagasse Ash (BA).

\begin{tabular}{|c|c|c|}
\hline \multirow{2}{*}{ Type of concrete } & \multicolumn{2}{|c|}{ Split Tensile Strength } \\
\cline { 2 - 3 } & 7 days & 28 days \\
\hline Normal concrete & 2.01 & 2.41 \\
\hline 5\% BA concrete & 2.00 & 2.62 \\
\hline 10\% BA concrete & 2.55 & 2.81 \\
\hline 20\% BA concrete & 2.53 & 3.25 \\
\hline $30 \%$ BA concrete & 1.69 & 2.62 \\
\hline
\end{tabular}

\section{CONCLUSION}

Sugar Cane Bagasse Ash is a waste product from Sugar Factory, available in huge quantity and have a great disposal problem leads to environmental pollution. Utilization of this waste product in the preparation of concrete is economical and also solve some environmental pollution issues.

From the experimental results it is concluded that, the Sugar Cane Bagasse Ash can be effectively utilized as cement replacement material up to $20 \%$. Because addition of SCBA as a cement replacement material has increased the compressive strength, Split Tensile strength and Flexural Strength of concrete up to $20 \%$, further addition of SCBA have an effect on strength and workability of concrete.

\section{REFERENCE}

[1] G. Sivakumar, V. Hariharan and S Barathan, (October2013) Preparation of Bio-cement using sugarcane bagasse ash and its Hydration behaviour, (IJSETR:Volume2, Issue10)

[2] Mrs.U.R.Kawade, Mr. V.R.Rathi, Miss Vaishali D. Girg, (July 2013), Effect of use of Bagasse Ash on Strength of Concrete, (IJIRSET, Vol. 2, Issue 7, ISSN:2278 -7798)

[3] Piyanut Muangtong, Suvimol Sujjavanich., Sansanee Boonsalee Sumate Poomiapiradee and Duangrudee Chaysuwan. (January 2013), Effects of Fine Bagasse Ash on the Workability and Compressive Strength of Mortars, (Chiang Mai Journal of Science 40 (1):126-134)

[4] Prashant O Modania and Vyawaharebnology M. R. (Dec 2013), Utilization of Bagasse Ash as a Partial Replacement of Fine Aggregate in Concrete, (Procedia Engineering 51:25-29, DOI: 10.1016/j.proeng. 2013.01.007)
[5] Shruthi H R1, Dr.H Eramma2,Yashwanth M K3, Keerthi Gowda B S4, (August 2014). A Study on bagasse ash replaced plain cement concrete, (IJATE Volume No.02, Issue No. 08)

[6] Singh N. B., Singh V. D. and Sarita Rai. (2000), Hydration of Bagasse Ash-Blended Portland Cement, (Journal of Cement \& Concrete Research, 30: 1485-1488)

[7] Sirirat Janjaturaphan and Supaporn Wansom. (December 2010), Pozzolanic Activity of Industrial Sugar Cane Bagasse Ash, (Suranaree J. Sci. Technol, 17(4): 349-357)

[8] SivaKumar M. And Dr. Mahindra N. (April 2013), Experimental Studies of Strength and Cost Analysis of ConcreteUsing Bagasse ASH, (IJERT, 2(4):1-8)

[9] T. S. Abdulkadir, D. O. Oyejobi, A. A. Lawal, (2014), Evaluation of Sugarcane bagasse ash as a replacement for Cement In concrete works, (Bulletin of Enginnering Tome; Jul-Sep2014, Vol. 7 Issue 3, p71)

[10] Dr M.P.S. Chauhan, Dr S.S Jain, Sanjay Srivastava, (November 2014) High Strength Concrete of M60 Grade for Highway Pavements for Heavy Vehicles, (IJSRP, Volume 4, Issue 11, 1 ISSN 2250-3153)

[11] N.Vidya Sagar Lal, G.Naveen, B.SomeswaraRao, (November 2015) Durability studies on concrete and comparison with partial replacement of cement with rise husk ash and sugarcane bagasse ash in concrete, ((IJERA), ISSN: 2248-9622, Vol. 5, Issue 11, (Part-4),pp. 52-58)

[12] Sagar W. Dhengare, Dr.S.P.Raut, N.V.Bandwal, Anand Khangan, (April 2015) Investigation into Utilization of Sugarcane Bagasse Ash as Supplementary Cementitious Material in Concrete, (IJEERT Volume 3, Issue 4, PP 109-116 ISSN 2349-4395)

[13] T. SHAFANA, R.VENKATASUBRAMANI, (January 2014) A study on the Mechanical Properties of Concrete with partial replacement of Fine aggregate with Sugarcane bagasse ash, (IJASGE ISSN 2319-5347, Vol. 03, No. 01) 